Taylor, R, B. (1962). Res. vet. Sci. 3,63.

Topps, J. H., Kay, R. N. B., Goodall, E. D., Whitelaw, F. G. \& Reid, R. S. (1968). Br. Y. Nutr. 22, 281 .

Ugolev, A. M. (xg65). Physial. Rev. 45, 555.

vaz Portugal, A. (1963). Some aspects of protein and amino acid metabolism in the rumen of the sheep. $\mathrm{PhD}$ Thesis, University of Aberdeen.

Virtanen, A. I. (1966). Science, N.Y. 153, 1603.

Weston, R. H. \& Hogan, J. P. (1967). Aust. F. biol. Sci. 5, 967.

Williams, V. J. (1965). Aust. F. agric. Res. r6, 77.

Wiseman, G. (1968). In Handbook of Physiology. Section 6. Alimentary Canal. Vol. 3. [C. F. Code and W. Heidel, editors.] Washington, DC: American Physiological Society.

\title{
Absorption of major minerals in the small and large intestines of the ruminant
}

\section{By R. H. Sмiтн, National Institute for Research in Dairying, Shinfield, Reading}

There is no reason to suppose that the intestines of ruminants differ basically from those of most non-ruminants in the way in which they handle minerals. Special factors peculiar to ruminants are most likely to be found in the nature of their diet and the modifying effects of the alimentary tract before the abomasum on that diet.

\section{Exchange of sodium, potassium and chloride in the intestines and the regulation of water content of the digesta}

Sodium and potassium contents of digesta entering the duodenum of non-ruminants, including non-ruminating calves, are influenced both by the diet and by endogenous factors. Passage of digesta down the small intestine of non-ruminating calves leads to a regulation of $\mathrm{Na}$ to $\mathrm{K}$ ratio so that in the ileum it depends upon the $\mathrm{Na}-\mathrm{K}$ status of the animal and little or not at all upon the immediately preceding $\mathrm{Na}$ or $\mathrm{K}$ intake. Calves fed successively on Na-deficient and K-deficient synthetic milks showed marked changes in ileal $\mathrm{Na}$ and $\mathrm{K}$ concentrations only after $\mathrm{I}$ or 2 days on the new diet, when adaptation had taken place. Values for ileal $\mathrm{Na}$ to $\mathrm{K}$ mole ratio then varied from about 0.3 to $\mathrm{I}_{3}$ for $\mathrm{Na}$-deficient and $\mathrm{K}$-deficient diets respectively compared with normal values of about $3-7$ (Smith, 1966). Similar adaptation to a low Na intake has been shown for the dog (Field, Swell, Dailey, Trout \& Boyd, 1955).

The amounts of $\mathrm{Na}$ and $\mathrm{K}$ reaching the ileum are the final result of net secretion of $\mathrm{Na}$ into the duodenum and subsequent net absorption of $\mathrm{Na}$ and $\mathrm{K}$ in the rest of the small intestine (Mylrea, 1966 and Fig. I). $\mathrm{K}$ absorption is probably passive (Donnet, Jacquin \& Fondarai, I963; Gilman, Koelle \& Ritchie, r963) but for the calf is none the less very efficient, at least with diets containing as much $\mathrm{K}$ as does milk (Smith, I962; Mylrea, 1966). It has frequently been demonstrated that $\mathrm{Na}$ is actively absorbed (Parsons, 1967) and, although the mechanism is unclear, it 
seems probable that $\mathrm{Na}, \mathrm{K}$ exchange is controlled by hormones of the adrenal cortex (Levitan \& Ingelfinger, 1965; Shields, Mulholland \& Elmslie, I966; Moll, 1967).
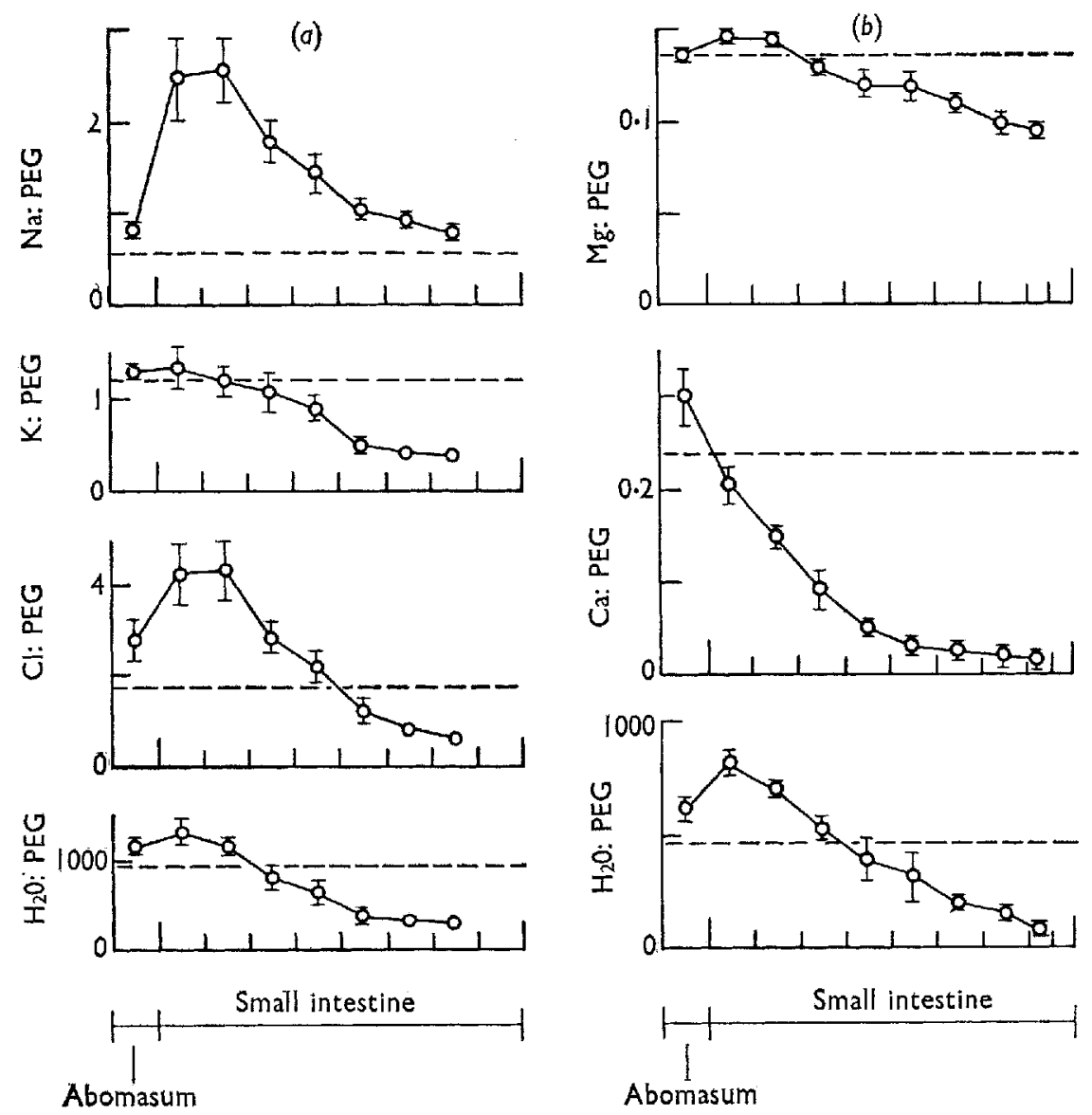

Fig. 1. Ratios of diet constituents to marker (polyethylene glycol (PEG)) (g/g) along the abomasum and small intestine of the non-ruminating calf. (a) Mean results with their standard errors for $\mathrm{Na}, \mathrm{K}$, $\mathrm{Cl}$ and water for five calves slaughtered $0.5-\mathrm{I}^{\prime} 5 \mathrm{~h}$ after feeding with a fat-free synthetic milk containing PEG. Results were obtained only up to the marker front which travelled further in some calves than in others, so that fewcr results were obtained for the more distal intestine. (b) Mean results with their standard errors for $\mathrm{Ca}, \mathrm{Mg}$ and water for four calves slaughtered $2.5-3 \mathrm{~h}$ after feeding with a solution containing $5 \%$ glucose, $0.013 \mathrm{M}-\mathrm{MgCl}_{2}, 0.013 \mathrm{M}-\mathrm{CaCl}_{2}$ and $\mathrm{PEG}$. Ratios in the diets are shown by horizontal broken lines.

In ruminants the pattern of $\mathrm{Na}$ secretion into the duodenum and net absorption of $\mathrm{Na}$ and $\mathrm{K}$ in the rest of the small intestine appears to be qualitatively similar to that shown by non-ruminants (van Weerden, I96I; Pfeffer, Bertzbach \& Lenkeit, I 967 ). The situation is, however, modified by the large amounts of saliva, with an $\mathrm{Na}$ to $\mathrm{K}$ ratio depending upon the $\mathrm{Na}-\mathrm{K}$ status of the animal (Kay, I960), added to the digesta and by absorption of $\mathrm{Na}$ and $\mathrm{K}$ before the abomasum (Scott, 1967 ). The $\mathrm{Na}$ and $\mathrm{K}$ concentrations in digesta entering the duodenum are therefore mainly 
controlled by endogenous factors. In six calves fed a normal hay and concentrate diet containing about $0 \cdot 25 \mathrm{~g} \mathrm{Na}$ and $\mathrm{r} \cdot 2 \mathrm{~g} \mathrm{~K}$ per roo g dry matter we found that the mean $\mathrm{Na}$ to $\mathrm{K}$ mole ratios in the proximal duodenum and distal ileum respectively were $2 \cdot 2 \pm 0 \cdot 2$ and $3 \cdot 2 \pm 0.3$. When the calves were put on to pasture containing about $0.09 \mathrm{~g} \mathrm{Na}$ and $2.3 \mathrm{~g} \mathrm{~K}$ per $100 \mathrm{~g}$ dry matter these ratios changed over a period of $\mathbf{I}-2$ weeks to $0.5 \pm 0 . \mathrm{I}$ and $0.4 \pm 0 . \mathrm{I}$ respectively. Similar, though less consistent, changes in the faeces were found, and this has also been shown for sheep (Devlin \& Roberts, 1963) and cows (Renkema, Senshu, Gaillard \& Brouwer, 1962). Adaptation to low $\mathrm{Na}$ intakes seems therefore to be a characteristic of ruminants as well as nonruminants although the process can sometimes be confused, in the short term, by changes in the volume and composition of rumen fluid causing $\mathrm{Na}$ to be temporarily retained in or released from this compartment (Dobson, Scott \& Bruce, I966). Nevertheless, adaptation is normally so efficient that cattle can have very low $\mathrm{Na}$ intakes for long periods without showing obvious clinical signs of $\mathrm{Na}$ deficiency although milk yield may be depressed (McDonald, r968). It should perhaps be borne in mind, however, that low levels of $\mathrm{Na}$ in the gut can lead to impaired utilization of other nutrients, particularly glucose and amino acids (Nelson \& Beargie, r965; Rosenberg, Coleman \& Rosenberg, 1965), and this does not seem to have been investigated in ruminants.

Most evidence suggests that water exchange in the small intestine is passive (Parsons, I 967 ). In the non-ruminating calf (Smith, 1966) and other non-ruminants (cf. Kalser, Williams, Peterson \& Smitherman, 1964) digesta are nearly isotonic by the time they reach the ileum and this is true also in sheep (Care, Vowles, Mann $\&$ Ross, 1967), ruminating calves (Smith, unpublished data) and adult cows (van Weerden, 1961). It appears that most absorption of water in the small intestine occurs secondarily to the absorption of osmotically active solutes. Some water is absorbed with low-molecular weight organic solutes but for much of the small intestine it is clear that absorption of $\mathrm{Na}$ and $\mathrm{K}$ (with associated anions) is the main governing factor. The amount of water remaining with the digesta at the ileum is usually closely related to the amounts of $\mathrm{Na}$ and $\mathrm{K}$ (and to a lesser extent magnesium) remaining at this site (Smith, 1966). In general, in our experiments with calves, changes in $\mathrm{Na}$ to $\mathrm{K}$ ratio have not been accompanied by consistent changes in the total moles of $(\mathrm{Na}+\mathrm{K})$ or water passing the ileum in unit time (Smith, I966, and unpublished data). Much information about ileal flow has been obtained by studying human subjects with ileostomies. In such patients it has usually been found that the amounts of water in digesta leaving the ileum in unit time are fairly constant for most diets (e.g. Kramer, Kearney \& Ingelfinger, 1962). Factors influencing ileal flow in non-ruminating calves have been discussed by Smith (1966), but for normal animals fed on milk the amounts of water passing the distal ileum were similar to those shown by human subjects. Ruminating calves and sheep, however, showed much greater amounts (Table I), and human subjects eating diets containing much indigestible roughage also showed a small increase (Kramer et al. 1962). These greater flows of water, associated with greater amounts of $(\mathrm{Na}+\mathrm{K})$, are clearly necessary to maintain the additional insoluble matter in a mobile condi- 


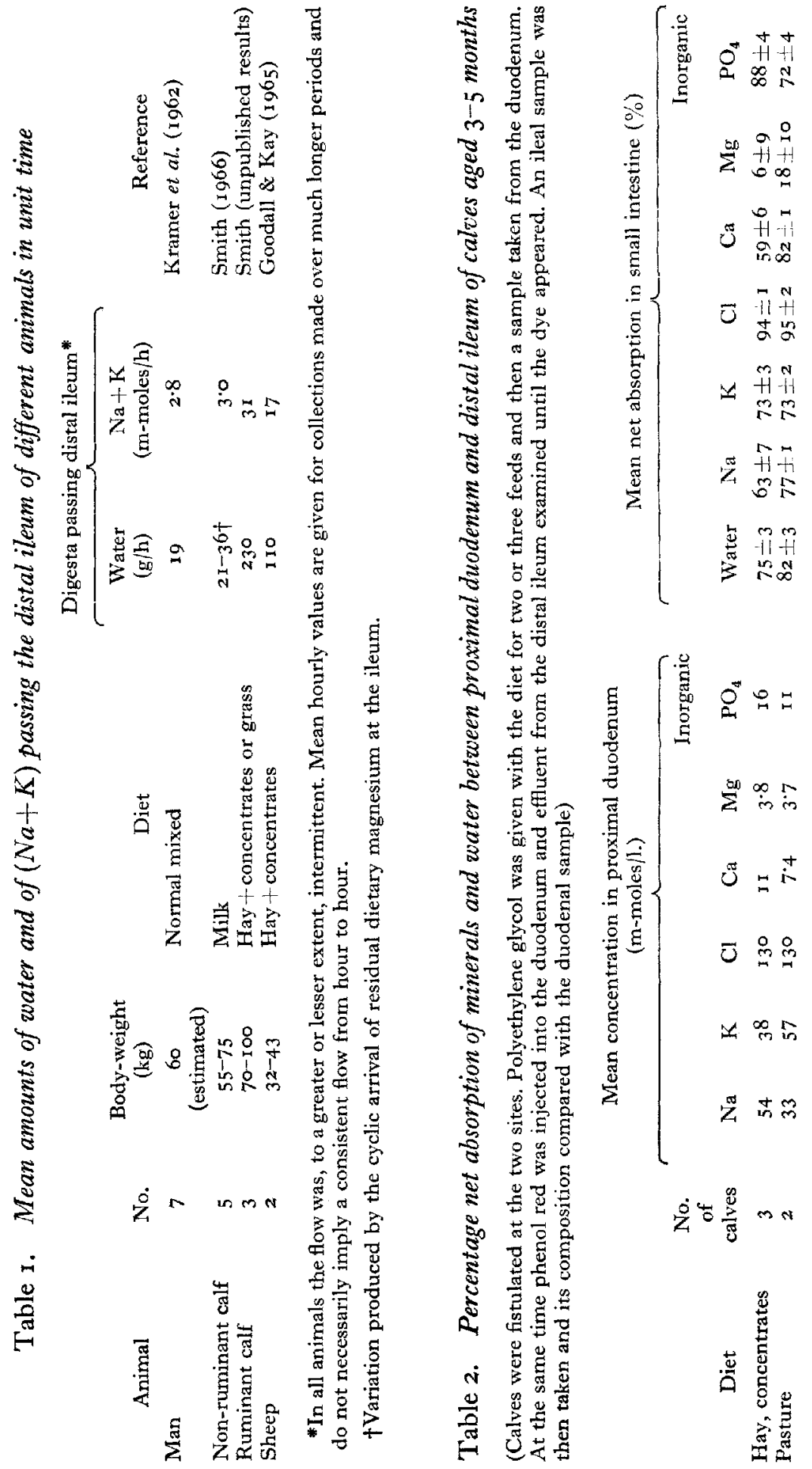


tion, but it is not clear how the control is exercised. The effect is to reduce net Na and $\mathrm{K}$ absorption up to the ileum in the ruminant, compared with the non-ruminant, and to lead to greater dilution of other solutes in the digesta at this site. This has particular significance for $\mathrm{Mg}$ and will be discussed later.

Evidence obtained with non-ruminating calves (Smith, I962), ruminating calves (Table 2), cows (van Weerden, 1961) and sheep (Pfeffer et al. 1967) shows that chloride is normally the major anion present in material entering the duodenum but is absorbed more effectively than $(\mathrm{Na}+\mathrm{K})$ in the small intestine where it is partly replaced by bicarbonate.

Sodium and chloride are very effectively absorbed in the large intestine of ruminants (van Weerden, I96r; Goodall \& Kay, 1965; Pfeffer et al. 1967) and nonruminating calves (Smith, 1962). Potassium is also absorbed but somewhat less efficiently so that the $\mathrm{Na}$ to $\mathrm{K}$ ratio always decreases between ileal contents and faeces. In the non-ruminating calf absorption of $\mathrm{K}$ and chloride in the large intestine is of little importance as only small amounts leave the distal ileum. Greater amounts of Na enter the large intestine but, even so, milk-fed calves may be kept with a discharging ileotomy for many weeks without serious effect (Smith, 1966). Similar considerations probably apply to non-ruminants in general, and human subjects with ileotomies live for many years without ill effects or any need for drastic mineral supplementation (cf. Kramer et al. 1962). However, with the large volume of digesta leaving the ileum in ruminants (Table $\mathrm{x}$ ), the large intestine may be of vital importance. Goodall \& Kay ( 1965$)$, for example, have shown that sheep on some diets pass more $\mathrm{Na}$ and chloride from the ileum than they ingest.

\section{Absorption of calcium and phosphate}

For several non-ruminant animals, in vitro experiments with everted sacs of intestine and perfusion experiments in vivo have shown that (a) $\mathrm{Ca}$ is actively absorbed from the small intestine with the absorption approaching a maximum rate with increasing concentration, (b) the process is most efficient in the proximal duodenum, (c) absorption is influenced by vitamin D (Schachter \& Rosen, I959; Wasserman, Kallfelz \& Comar, I96r; Cramer \& Dueck, 1962; Schachter, Kowarski \& Finkelstein, 1964; Krawitt \& Schedl, 1968). Absorption is also controlled by endogenous factors and improves with Ca depletion (e.g. Hansard, Comar \& Plumlee, 1951). Parathyroid hormone may be responsible for governing this adaptation (Shah \& Draper, 1966). Efficiency of $\mathrm{Ca}$ absorption also decreases with increasing age (Hansard \& Crowder, 1957) and is affected by other endogenous (e.g. oestrogens and thyroxine) and dietary (e.g. lactose and certain amino acids) factors. It may be depressed by gut stasis, and Moodie \& Robertson (1962) have suggested that this may be a contributory factor in clinical hypocalcaemia at parturition (milk fever). The controversial subject of $\mathrm{Ca}-\mathrm{Mg}$ interrelationships is discussed in the next section.

Absorption of $\mathrm{Ca}$ by ruminants appears to follow a general pattern similar to that shown by non-ruminants. Thus, for example, it is influenced by vitamin D (Wallis, Palmer \& Gullickson, 1935; Conrad, Hansard \& Hibbs, 1956), by $\mathrm{Ca}$ status of the animal (Manston, 1967) and by age (Hansard, Comar \& Plumlee, 1954). 
In the milk-fed calf, absorption of Ca was very effective in the proximal small intestine (Fig. I) as would be expected from the general findings for non-ruminants described above. It is not clear whether the finding of Phillipson \& Storry (1965) that net absorption of $\mathrm{Ca}$ occurred only below the bile duct in sheep represents a real difference for this animal or a more precise location of the site studied. It may be related to the effect of bile salts on Ca absorption reported by Webling \& Holdsworth (1966).

Absorption of $\mathrm{Ca}$ in the non-ruminant can be depressed by dietary factors, such as phytate, which precipitate or bind $\mathrm{Ca}$ in the small intestine. In the ruminant such substances may be destroyed in the rumen but others may be elaborated. Storry $(\mathrm{I} 96 \mathrm{I} b$ ) showed that abomasal digesta of sheep contain materials which bind $\mathrm{Ca}$ above $\mathrm{pH}$ 5. Nucleic acids which are formed in the rumen and pass largely unchanged to the duodenum (Smith, McAllan \& Hill, I968) are potent Ca-binding agents down to about $\mathrm{pH} 5$ (Chang \& Carr, 1968) and were presumably in part responsible for this binding. Other Ca-binding agents have been demonstrated in the calf ileum (Smith \& McAllen, 1966). It seems that the poorer net absorption of $\mathrm{Ca}$ in the small intestine shown by ruminating calves (Table 2) compared with milk-fed calves (Smith, I 962) and the poorer overall $\mathrm{Ca}$ absorption which they show (Lengemann, Comar \& Wasserman, 1957) is due, at least partly, to these binding materials.

There is no evidence to show that $\mathrm{Ca}$ is absorbed appreciably in the large intestine, and in the milk-fed calf there was virtually no net exchange of $\mathrm{Ca}$ between ileal contents and faeces (Smith, rg62).

With different animals, excessive amounts of either $\mathrm{Ca}$ or phosphate in the diet have sometimes been found to interfere with absorption of the other ion (O'Dell, Morris, Pickett \& Hogan, 1957; Compère, 1965), presumably, in part, by leading to precipitation of insoluble calcium phosphate. Cattle and sheep, however, appear able to tolerate quite a wide range of $\mathrm{Ca}$ to $\mathrm{P}$ ratios in their diet without any serious interference in the utilization of either (Bohstedt, 1942; Young, Richards, Lofgreen \& Luick, 1966). Precipitation of calcium phosphate certainly occurs in the small intestine of ruminating and non-ruminating calves even with normal intakes (Smith \& McAllan, I966), but only where the $\mathrm{pH}$ exceeds about 6.5 and not therefore in the middle and upper small intestine where most absorption of $\mathrm{Ca}$ and probably phosphate occurs.

Inorganic phosphate is absorbed very efficiently in the small intestine of both the ruminating and non-ruminating calf (Smith, I966, and Table 2). Little is known of the mechanism of absorption although the in vitro results of Harrison \& Harrison (196r) suggest that active transport might be involved. Adaptation in net absorption efficiency with changing $\mathrm{P}$ intakes has been demonstrated in the sheep (Young, Lofgreen \& Luick, 1966).

\section{Absorption of magnesium}

Up to about I month of age calves absorb $\mathrm{Mg}$ in the large as well as the small intestine (Smith, 1962), giving efficient overall net absorption (about $70-90 \%$ intake). This ability is lost with increasing age until by about $3^{-4}$ months the 
small intestine is the only important absorption site. This also seems to be the main site of $\mathrm{Mg}$ absorption in adult sheep (Field, I96I), rabbits (Aikawa, 1959) and human subjects (Graham, Caesar \& Burgen, 1960). In non-ruminating calves net $\mathrm{Mg}$ absorption appears to occur slowly over much of the small intestine (Fig. I), is not very efficient even when milk or simple magnesium chloride solutions are fed (about $20-40 \%$ intake (Smith, 1962 and unpublished data)), and shows no tendency to adapt in $\mathrm{Mg}$ deficiency. Net absorption in the small intestine or whole alimentary tract of ruminating calves is however even less efficient (Smith, I959 and Table 2) and a large loss of $\mathrm{Mg}$ in the faeces (usually about $70^{\circ-95 \%}$ intake) appears to be a characteristic of adult cattle and sheep (Rook \& Storry, I962; Field, I962). Most of this faecal loss appears to consist of unabsorbed food $\mathrm{Mg}$ with normal intakes (Blaxter \& McGill, 1956; Field, 1959).

Experiments to examine the possibility of competition between $\mathrm{Mg}$ and $\mathrm{Ca}$ for absorption in the gut, which might, if established, provide evidence of active $\mathrm{Mg}$ absorption, have given contradictory results. In experiments by different workers each of these elements has been shown to depress, have no effect upon or improve absorption of the other. In non-ruminating calves we found no effect. Some of these experiments have been discussed by Smith ( $1964 a$ ) and more recent work has not resolved the matter (Clark, 1965; Kessner \& Epstein, 1966; Lifshitz, Harrison \& Harrison, 1967). However, it appears that, at least in the calf, $\mathrm{Mg}$ absorption in the gut has quite a different pattern to that of $\mathrm{Ca}$ (Fig. I) and is not appreciably influenced by vitamin D (Smith, 1958). Furthermore, no experiments have ever demonstrated transport of $\mathrm{Mg}$ across the gut wall against an electrochemical gradient. In fact, the low efficiency of $\mathrm{Mg}$ absorption and the apparently unlimited increase (unless diarrhoea occurred) in amounts absorbed with increasing intake shown by a number of animals (Smith, 1959, I962; Graham et al. 1960; Heaton \& Parsons, r961; Chutkow, I964) strongly suggest passive absorption. As would be expected, because high concentrations of $\mathrm{Mg}$ retain water osmotically in the gut (Smith, 1966 ), percentage absorption tended to decrease at high intakes but there was no indication of the absorption mechanism becoming saturated. Scott ( I $_{95}$ ) has calculated that, before passive diffusion from small intestine lumen to blood could occur, $\mathrm{Mg}$ concentrations in the digesta of above about $\mathrm{I} \cdot 4-2 \cdot \mathrm{I} \mathrm{m}$-moles/l. would be necessary to overcome the fairly small electrical potential $(7-15 \mathrm{mV}$, blood positive) across the wall of the small intestine of the sheep. Care \& van't Klooster (1965) found that $\mathrm{Mg}$ absorption from ileal loops occurred only above about this concentration. Digesta from non-ruminating calves and ruminants normally contain appreciably higher total $\mathrm{Mg}$ concentrations than this, at least in the ileum(Smith, r 962; Smith \& McAllan 1966; Storry, I96ra; and Table 2), but all the $\mathrm{Mg}$ is not necessarily in an available ionic form (see below).

Suttle \& Field ( 1967 ) found that high $\mathrm{K}$ intakes depressed $\mathrm{Mg}$ absorption in the sheep although we have not found this to be so in non-ruminating calves (unpublished observation). The finding in sheep may be related to changes in aldosterone production since aldosterone infusion has been shown to depress plasma $\mathrm{Mg}$ in sheep (Care \& Ross, r963; Scott \& Dobson, 1965) and apparent changes in aldo28 (I) II 
sterone status, as a result of changes in dietary $K$, have been related to falls in plasma Mg in sheep going on to pasture (Dobson, Scott \& McDonald, 1966). The mechanism of these interactions is, however, not clear and the results do not provide evidence of interference with an active $\mathrm{Mg}$ absorption process. One possibility is that high $\mathrm{K}$, low $\mathrm{Na}$ concentrations in the small intestine are associated with an increase in the electrical potential between digesta and blood, as they are in the sheep rumen (Sellers \& Dobson, 1960 ) and rat colon (Edmonds, 1967 ).

If it is accepted that $\mathrm{Mg}$ moves passively across the wall of the small intestine then it appears that the only factors (apart from electrical potential) which are likely to be responsible for major differences in the efficiency of $\mathrm{Mg}$ absorption are the concentration of available $\mathrm{Mg}$ in the digesta and the time of contact between the digesta and the absorbing surface. The latter depends upon transit time through the small intestine and this has been shown to be related to the efficiency of $\mathrm{Mg}$ absorption in the non-ruminating calf (Smith, 1963). Transit time variation can be responsible for animal-to-animal variation in this efficiency but there is no evidence to show that it is responsible for differences between one ruminant diet and another (Smith, $1964 b$ ). Concentrations of $\mathrm{Mg}$ ions in the digesta in the small intestine of ruminants tend to be low because of the large amounts of water retained in the ileum (Table I) and the presence in the digesta of materials able to bind $\mathrm{Mg}$ at intestinal $\mathrm{pH}$. Such materials have been demonstrated in the abomasum of sheep (Storry, I $96 \mathrm{r} b$ ) and ileum of ruminating calves (Smith \& McAllan, I 966 ). Lowering of ultrafiltrable $\mathrm{Mg}$ in the calf ileum was due partly to a variable precipitation with phosphate (usually as a mixed $\mathrm{Ca}-\mathrm{Mg}$ phosphate rather than as $\mathrm{MgNI}_{4} \mathrm{PO}_{4}(\mathrm{Smith}$ \& McAllan, 1967)) and partly to binding independent of phosphate. The latter was estimated to account for $30-45 \%$ of the $\mathrm{Mg}$ in calf ileal contents but did not increase in calves put on to spring pasture.

Clinical hypomagnesaemia in cattle and sheep is usually associated with transferring the animals on to spring pasture. Grass causing the condition often has rather a low $\mathrm{Mg}$ content (Butler et al. 1963; Larvor \& Guéguen, 1963) and drymatter intakes may be low in animals when they are first put on to such pasture (Rohr \& Kaufmann, 1967). These factors combined with the characteristically poor $\mathrm{Mg}$ absorption shown by ruminants are probably enough in themselves to cause clinical hypomagnesaemia in some animals. Nevertheless, it appears also that the efficiency of $\mathrm{Mg}$ absorption from a diet of spring grass is less than from most stall diets (Rook \& Campling, 1962; L'Estrange, Owen \& Wilman, 1967). Many theories have been put forward in attempts to account for this reduced absorption, mostly based on the presence of factors which might reduce $\mathrm{Mg}$ availability in the digesta. None offers an adequate explanation of the phenomenon, but the presence of certain organic acids in pasture grass which might chelate $\mathrm{Mg}$ in the gut (Burt \& Thomas, I96r; Stout, Brownell \& Burau, 1967) merits further investigation.

\section{REFERENCES}

Aikawa, J. K. (1959). Proc. Soc. exp. Biol. Med. 1oo, 293.

Blaxter, K. L. \& McGill, R. F. (1956). Vet. Rev. Annot. 2, 35. 


\section{Vol. 28 Digestion in the abomasum and intestine of the ruminant}

Bohstedt, G. (1942). F. Dairy Sci. 25, 44 ז.

Burt, A. W. A. \& Thomas, D. C. (1961). Nature, Lond. 192, I193.

Butler, E. J. et al. ( $\left.\mathrm{Ig}_{3}\right)$. F. agric. Sci., Camb. 60, 329.

Care, A. D. \& Ross, D. B. (1963). Res. vet. Sci. 4, 24.

Care, A. D. \& van't Klooster, A. Th. (1965). F. Physiol, Lond. I77, 174.

Care, A. D., Vowles, L. E., Mann, S. O. \& Ross, D. B. (1967). J. agric. Sci., Camb. 68, 195.

Chang, K. Y. \& Carr, C. W. (I968). Biochim. biophys. Acta 157, 127.

Chutkow, J. G. (1964). 7. Lab. clin. Med. 63, 80.

Clark, I. (1965). Nature, Land. 207, 982.

Compère, R. (1965). Bull. Inst. agron. Stns Rech. Gembloux 33, 173.

Conrad, H. R., Hansard, S. L. \& Hibbs, J. W. (1956). Y. Dairy Sci. 39, 1697.

Cramer, C. F. \& Dueck, J. (1962). Am. F. Physiol. 202, I61.

Devlin, T. J. \& Roberts, W. K. (rg63). 7. Anim. Sci. 22, 648.

Dobson, A., Scott, D. \& Bruce, J. B. (1966). Q. Fl exp. Physiol. 5I, 3 I I.

Dobson, A., Scott, D. \& McDonald, I. (1966). Res. vet. Sci. 7, 94 .

Donnet, V., Jacquin, M. \& Fondarai, J. (1963). C. r. Séanc. Soc. Biol. 157, 322.

Edmonds, C. J. (1967). F. Physiol, Lond. 193, 589.

Field, A. C. (1959). Nature, Lond. 183, 983 .

Field, A. C. (196r). Br. F. Nutr. 15, 349.

Field, A. C. (1962). Br. F. Nutr. 16, 99.

Field, H., Swell, L., Dailey, R. E., Trout, E. C. \& Boyd, R. S. (1955). Circulation 12, 625.

Gilman, A., Koelle, E. \& Ritchie, J. M. (1963). Nature, Lond. 197, 1210.

Goodall, E. D. \& Kay, R. N. B. (1965). F. Physiol., Lond. 176, I2.

Graham, L. A., Caesar, J. J. \& Burgen, A. S. V. ( ( 960). Metabolism 9, 646.

Hansard, S. L., Comar, C. L. \& Plumlec, M. P. (I951). Proc. Soc. exp. Biol. Med. 78, 455.

Hansard, S. L., Comar, C. L. \& Plumlee, M. P. (I954). J. Anim. Sci. 13, 25.

Hansard, S. L. \& Crowder, H. M. (1957). F. Nutr. 62, 325 .

Itarrison, H. E. \& Harrison, H. C. (r $96 \mathrm{I}$ ). Am. F. Physiol. 2or, 1007.

Heaton, I. W. \& Parsons, F. M. (1961). Clin. Sci. 21, 273.

Kalscr, M. H., Williams, R. M., Peterson, A. R. \& Smitherman, B. (1964). Gastroenterology 46, 260.

Kay, R. N. B. (1960). F. Physiol, Lond. 150, 515.

Kessner, D. M. \& Epstein, F. H. (I966). Proc. Soc. exp. Biol. Med. 122, 72 r.

Kramer, P., Kearney, M. M. \& Ingelfinger, F. J. (1962). Gastroenterology 42, 535.

Krawitt, E. L. \& Schedl, H. P. (1968). Am. F. Physiol. 214, 232.

Larvor, P. \& Guéguen, L. (r 963). Annls Zootech. I2, 39.

Lengemann, F. W., Comar, C. L. \& Wasserman, R. H. (I957). 7. Nutr. 6r, 57 r.

L'Estrange, J. L., Owen, J. B. \& Wilman, D. (1967). F. agric. Sci., Camb. 68, 173.

Levitan, R. \& Ingelfinger, F. J. (1965). F. clin. Invest. 44, 801.

Lifshitz, F., Harrison, H, C. \& Harrison, H. E. (1967). Proc. Soc, exp. Biol. Med. 125, 19.

McDonald, I. W. (I 968). Nutr. Abstr. Rev. 38, 38 r.

Manston, R. (1967). F. agric. Sci., Camb. 68, 263 .

Moll, H. C. (1967). In Recent Advances in Gastroenterology. Vol. 2, p. 398. Tokyo: 3 rd World Congress of Gastroenterology.

Moodie, E. W. \& Robertson, A. (1 962). Res. vet. Sci. 3, 470.

Mylrea, P. J. (1966). Res, vet. Sci. 7, 394.

Nelson, R. A. \& Beargie, R. J. (1965). Am. F. Physiol. 208, 375.

O'Dell, B. L., Morris, E. R., Pickett, E. E. \& Hogan, A. G. (I957). F. Nutr. 63, 65.

Parsons, D. S. (1967). Proc. Nutr. Soc. 26, 46 .

Pfeffer, E., Bertzbach, J. \& Lenkeit, W. (1967). Z. Tierphysiol. Tierernähr. Futtermittelk. 22, 15.

Phillipson, A. T. \& Storry, J. E. (I965). F. Physiol., Lond. 18r, 130.

Renkema, J. A., Senshu, T., Gaillard, B. D. E. \& Brouwer, E. (1962). Nature, Lond. 195, $3^{89}$.

Rohr, K. \& Kaufmann, W. (1967). Wirtschaftseigene Futter, 13,85.

Rook, J. A. F. \& Campling, R. C. (1962). F. agric. Sci, Camb. 59, 225.

Rook, J. A. F. \& Storry, J. E. (1962). Nutr. Abstr. Rev. 32, 1055.

Rosenberg, I. H., Coleman, A. L. \& Rosenberg, L. E. (1965). Biochim. biophys. Acta I02, I6 г.

Schachter, D., Kowarski, S. \& Finkelstein, J. D. (1964). Science, N.Y. 143, I43.

Schachter, D. \& Rosen, S. M. (1959). Am. F. Physiol. 196, 357.

Scott, D. (1965). Q. fl exp. Physiol. 50, 312.

Scott, D. (1967). Q. Yl exp. Physiol. 52, 382.

Scott, D. \& Dobson, A. (I965). Q. Fl exp. Physiol. 50, 42.

Sellers, A. F. \& Dobson, A. (1960). Res. vet. Sci. r, 95.

Shah, B. G. \& Draper, H. H. (1966). Am. F. Physiol. 211, 963. 
Shields, R., Mulholland, A. T. \& Elmslie, R. G. (1966). Gut 7, 686.

Smith, R. H. (1958). Biochem. F. 70, $20 \mathrm{r}$.

Smith, R. H. (1959). Biochem. F. 71, 306.

Smith, R. H. (1962). Biochem. F. 83, 151 .

Smith, R. H. (1963). Nature, Lond. 198,161 .

Smith, R. H. (1964a). Nord.VelMed. 16, suppl. 1, p. I43.

Smith, R. H. (1964b). F. Physiol., Lond. 172, 305.

Smith, R. H. (1966). F. Physiol., Lond. 183, 532 .

Smith, R. H. \& McAllan, A. B. (1966). Br. F. Nutr. 20, 703.

Smith, R. H. \& McAllan, A. B. (1967). Proc. Nutr. Soc. 26, xxxii.

Smith, R. H., McAllan, A. B. \& Hill, W. B. (1968). Proc. Nutr. Soc. 27, 48 A.

Storry, J. E. (1961a). F. agric. Sci., Camb. 57, 97.

Storry, J. E. ( ( $96 \mathrm{~s} b)$ ). F. agric. Sci, Camb. 57, 103.

Stout, P. R., Brownell, J. \& Burau, R. G. (1967). Agrun. F. 59, 2 I.

Suttle, N. F. \& Field, A. C. (1967). Br. Y. Nutr. 21, 819.

van Weerden, E. J. (1961). F. agric. Sci., Camb. 56, 317 .

Wallis, G. C., Palmer, L. S. \& Gullickson, T. W. (1935). F. Dairy Sci. 18, 213.

Wasserman, R. H., Kallfelz, F. A. \& Comar, C. L. (196r). Science, N.Y. 133,883.

Webling, D. D'A. \& Holdsworth, E. S. (rg66). Biochem. J. roo, 652.

Young, V. R, Lofgreen, G. P. \& Luick, J. R. (I966). Br. F. Nutr. 20, 795.

Young, V. R., Richards, W. P. C., Lofgreen, G. P. \& Luick, J. R. (1966). Br. F. Nutr. 20, 783.

\section{Diarrhoea of nutritional origin}

By J. H. B. Roy, National Institute for Research in Dairying, Shinfield, Reading

\section{Definition}

For the purpose of this paper, diarrhoea will be defined as the condition in which faeces containing less than I $2 \%$ dry matter are produced. It may be the result of poor absorption of water from, or increased secretion of water into, the alimentary tract, or in certain cases a reduced excretion of faecal dry matter.

\section{Economic importance}

The economic importance of diarrhoea in the ruminant animal is mainly of relevance in the nutrition at the pre-ruminant stage. In a recent survey of calf wastage (Leech, Macrae \& Menzies, I 968) 8.9\% of 40000 calves were affected with diarrhoea on some occasion during the Ist year of life. The cause of death in $44.9 \%$ of $35^{\circ}$ post-mortem examinations was classified as being due to gastrointestinal disorders, with a further $24.8 \%$ resulting from septicaemia. Since an earlier survey of 2046 post-mortem examinations showed that Escherichia coli was associated with $46 \%$ of deaths up to 6 months of age and Salmonella with $24 \%$ (Veterinary Investigation Service, I964), the great majority of the gastro-intestinal disorders are clearly associated with colibacillosis. Most of the mortality from diarrhoea occurs at a young age and, in the survey of Leech et al. (1968), the probability of death at any time in home-bred calves was about equal to the reciprocal of age, and percentage mortality up to age $W$ (in weeks) was equal to $\log _{e} W+r^{\circ} 72$. 